\title{
Relationship Between Sheep Farmer's Characteristics with the Animal and Environmental Health Management Practices in Batur Village, Banjarnegara, Indonesia
}

\author{
Alek Ibrahim ${ }^{1}$, Deny Setyo Wibowo ${ }^{1}$, I Gede Suparta Budisatria ${ }^{2}$, Rini Widayanti $^{1}$, and \\ Wayan Tunas Artama ${ }^{1 *}$ \\ ${ }^{1}$ Faculty of Veterinary Medicine, Universitas Gadjah Mada, J1. Fauna No. 2, Karangmalang, \\ Yogyakarta 55281, Indonesia \\ ${ }^{2}$ Faculty of Animal Science, Universitas Gadjah Mada, Jl. Fauna No.3, Karangmalang, Yogyakarta \\ 55281, Indonesia
}

\begin{abstract}
The success of animal husbandry is supported by good animal and environmental health management practices. This study examined the correlation between the sheep farmer's characteristics and the animal and environmental health management practices. The data collected by direct interviews with 48 respondents in Batur Village, Banjarnegara. Indonesia. The aspects of animal (exercise, grooming, wool shearing, supplement feeding, and water drinking) and environmental (sheepfold sanitation, waste processing, and waste removal) health management practices were divided into three categories, namely low, medium, and high levels. The results showed that $83.3 \%$ of respondents were in the low-level following by medium $(14.6 \%)$ and high $(2.1 \%)$ levels of animal health management. Furthermore, on the environmental health management shows, $27.1 \%$ of respondents were in the low level, $60.4 \%$ in the medium level, and $12.5 \%$ in the high level. There was a significant relationship between farmers' characteristics (informal education, livestock farming experience, and the number of sheep) and animal health management practice. A significant relationship was also shown between formal education, livestock purpose, livestock experience, and number of sheep by farmers toward environmental health management practice. It may conclude that the low and medium levels of animal and environmental health management practices were dominant in Batur Village.
\end{abstract}

Keywords: correlation analysis, farmers activities, management practice, smallholder farmers

\section{Introduction}

Batur Village is located in Batur District, Banjarnegara Regency, Central Java Province, Indonesia. This village has an area of 1,212.42 ha and an altitude of 1,666 m above sea level.

* Corresponding author: artama@ugm.ac.id 
This area has a temperature of $14-20^{\circ} \mathrm{C}$, humidity of $84-85 \%$, and rainfall of $2,238 \mathrm{~mm} / \mathrm{year}$ [1]. This village relatively cold for a tropical area, the majority of the society creates horticultural lands and plantations. This condition potentially to developing livestock business due to the availability of forage and it could be improved to create an integrated farming system in this area. Sheep breeding is one of the most popular livestock businesses that developed in Batur Village. Batur sheep have been developed by the community in Batur District and its surroundings since 1974 and designated as one of the Indonesian local sheep breeds through the Decree of the Ministry of Agriculture of the Republic of Indonesia No. 2916/Kpts/OT.140/6/2011. This breed is the result of a crossbreeding between the Thin Tailed sheep and Merino sheep. These breeds typically have soft and dense wool that almost covering the entire body surface with body weights up to $108 \mathrm{~kg}$ for males and $82 \mathrm{~kg}$ for females. Both male and female Batur sheep are hornless and relatively calm temperament [2]. This sheep is suitable for developing in areas with low temperature and high humidity environmental conditions such as in Batur Village, Banjarnegara Regency, Indonesia [3-5].

The important thing to achieve optimal productivity is the application of good health management. The provision of a suitable house is an important factor to maintain the safety, comfort, and productivity of the livestock. Good biosecurity practices need to be done, for example, by regularly cleaning the house area, the feces under the cage also needs to be regularly cleaned. The balanced nutrient content in feed management will affect optimal productivity. The implementation of good animal and environmental health management practices is an inseparable part of the sheep farming system. Good management practice in animal health and environmental health will enhance productivity and the benefits. Regarding the condition and potentials that exist in Batur Village, there are business tips by farmers in implementing sheep care management, including good practice in aspects of animal and environmental health management.

Public health, animal health, or environmental health is the wholeness and integrity of the living system. It does not just prevent the illness of animals, but the maintenance of physical, psychological, social, and ecological well-being [6]. One health is a concept that integrates human and animal health through research from multidisciplinary and intersectoral collaborations and international policy. The One Health concept refers to the health connection between humans, animals, and shared ecosystems that aim to achieve optimal health for humans, animals, and the environment [7-9]. The concept's achievement is influenced by the human-animal-environment interaction and socio-ecological behavior [10]. The application of livestock management in a certain area and with certain geographic conditions will be influenced by the demographic characteristics of farmers in that area [11]. This is supported by several research results which state that the characteristics of farmers will affect the level of adoption of livestock technology, livestock business management, and also outbreaks of infectious diseases [12-15]. Individual characteristics also important factors that are related to all aspects of life and the environment. Individual characters which include motives, values, personality traits, and interaction with each other, also interaction with the environmental factors which contribute to determining the individual behavior [16]. Farmers' characteristics are very important to be studied, as a first step to measure the success of livestock management [17]. This study aims to examine the relationship between the sheep farmers' characteristics and the animal and environmental health management practices in Batur Village.

The important thing to achieve optimal productivity is the application of good health management. The provision of a suitable house is an important factor to maintain the safety, comfort, and productivity of the livestock. Good biosecurity practices need to be done, for example, by regularly cleaning the house area, the feces under the cage also needs to be regularly cleaned. The balanced nutrient content in feed management will affect optimal productivity. The implementation of good animal and environmental health management 
practices is an inseparable part of the sheep farming system. Good management practice in animal health and environmental health will enhance productivity and the benefits. Regarding the condition and potentials that exist in Batur Village, there are business tips by farmers in implementing sheep care management, including good practice in aspects of animal and environmental health management.

Public health, animal health, or environmental health is the wholeness and integrity of the living system. It does not just prevent the illness of animals, but the maintenance of physical, psychological, social, and ecological well-being [6]. The application of livestock management in a certain area and with certain geographic conditions will be influenced by the demographic characteristics of farmers in that area [11]. This is supported by several research results which state that the characteristics of farmers will affect the level of adoption of livestock technology and also livestock business management [12-14]. Individual characteristics also important factors that are related to all aspects of life and the environment. Individual characters which include motives, values, personality traits, and interaction with each other, also interaction with the environmental factors which contribute to determining the individual behavior [16]. Farmers' characteristics are very important to be studied, as a first step to measure the success of livestock management [17]. This study aims to examine the relationship between the sheep farmers' characteristics and the animal and environmental health management practices in Batur Village.

\section{Methodology}

\subsection{Ethical approval}

This study was approved by the Animal Care and Use Committee of the Faculty of Veterinary Medicine, Universitas Gadjah Mada, with the ethical clearance number 002/ECFKH/Int/2019, and the National Political and Unity of Yogyakarta Special Region with the approval number 074/1850/Kesbangpol/2019.

\subsection{Study area, period, and design}

This study was conducted in Batur Village, Banjarnegara Regency, Central Java Province, Indonesia. The data collected by direct interviews with 48 respondents of sheep farmers from November 2019 to April 2020. A semi-structured questionnaire was used to collect information about farmers' characteristics, farm characteristics, and the management practices that were used by farmers for animal and environmental health management aspects. All the variables are defined in Table 1.

The aspects of health management observed in this study including animal health management practices and environmental health management practices. These aspects are presented in Table 2. Livestock health management practices include exercise, grooming, wool shearing, supplement feeding, and water drinking. Environmental health management practices include sheepfold sanitation, waste processing, and waste removal. Based on the aspects of animal and environmental health management that practiced by farmers they were given score differently, then divided into 3 categories, namely low, medium, and high levels. Low level was categorized if farmer has score 5 to 7 for animal health management practice and 3 to 5 for environmental health management practice. The medium level was categorized if the farmer has a score of 8 to 10 for animal health management practice and 6 to 7 for environmental health management practice. A high level was categorized if the farmer has a score of 11 to 12. Descriptive statistic of the variables is presented in Table 3, while the level of application of livestock health and environmental management is presented in Figure 1. The Spearman's rank correlation between the farmers' characteristics and the animal and 
environmental health management practices levels examined using SPSS program version 25 (IBM Inc, USA).

Table 1. Variables' definitions and their measurement

\begin{tabular}{|c|c|c|}
\hline Variables & Definitions & Type of measurement \\
\hline \multicolumn{3}{|l|}{$\begin{array}{l}\text { Dependent } \\
\text { categories }\end{array}$} \\
\hline $\begin{array}{l}\text { a. Animal health } \\
\text { management }\end{array}$ & $\begin{array}{l}\text { The level of practice of the } \\
\text { livestock (sheep) health } \\
\text { management aspect used by } \\
\text { farmers dividing into } 3 \\
\text { categories }\end{array}$ & $\begin{array}{l}\text { Categorical (1=Low, } \\
2=\text { Medium, 3=High) }\end{array}$ \\
\hline $\begin{array}{l}\text { b. Environment } \\
\text { health } \\
\text { management }\end{array}$ & $\begin{array}{l}\text { The level of practice of the } \\
\text { environmental health } \\
\text { management aspect used by } \\
\text { farmers dividing into } 3 \\
\text { categories }\end{array}$ & $\begin{array}{l}\text { Categorical (1=Low, } \\
2=\text { Medium, 3=High) }\end{array}$ \\
\hline \multicolumn{3}{|l|}{\begin{tabular}{|l|} 
Independent \\
variables
\end{tabular}} \\
\hline a. Age & $\begin{array}{c}\text { Age of the main farmers in the } \\
\text { household in years }\end{array}$ & $\begin{array}{c}\text { Dummy }(1=\text { less than } 30,2= \\
30<40,3=40<50,4=50<60 \\
5=\text { more than or equal to } 60 \\
\text { years }\end{array}$ \\
\hline $\begin{array}{l}\text { b. Formal } \\
\text { education }\end{array}$ & Farmers' formal education & $\begin{array}{l}\text { Dummy (1= no school; } 2= \\
\text { elementary school, } 3=\text { junior- } \\
\text { high school, } 4=\text { senior-high } \\
\text { school; } 5=\text { college graduate })\end{array}$ \\
\hline c. Main works & $\begin{array}{l}\text { The main work of the } \\
\text { respondent }\end{array}$ & $\begin{array}{c}\text { Dummy }(1=\text { sheep farmers, } 2= \\
\text { crop farmers, } 3=\text { farm workers, } \\
4=\text { traders, } 5=\text { village officials, } \\
6=\text { others })\end{array}$ \\
\hline d. Size household & $\begin{array}{c}\text { Total number of people in the } \\
\text { household }\end{array}$ & $\begin{array}{c}\text { Dummy }(1=1-2,2=3-4,3=5-6 \\
\text { members })\end{array}$ \\
\hline e. Family labor & $\begin{array}{l}\text { Total number of people in the } \\
\text { household as labor on animal } \\
\text { husbandry activities }\end{array}$ & $\begin{array}{c}\text { Dummy }(1=1-2,2=3-4,3=5-6 \\
\text { members })\end{array}$ \\
\hline $\begin{array}{l}\text { f. } \begin{array}{l}\text { Livestock } \\
\text { purpose }\end{array} \\
\end{array}$ & $\begin{array}{l}\text { The main purpose of raising } \\
\text { livestock }\end{array}$ & $\begin{array}{c}\text { Dummy }(1=\text { primary purpose } \\
2=\text { secondary purpose } \\
3=\text { hobby })\end{array}$ \\
\hline $\begin{array}{l}\text { g. Livestock } \\
\text { experience }\end{array}$ & $\begin{array}{l}\text { Experience in raising livestock } \\
\text { in year }\end{array}$ & $\begin{array}{l}\text { Dummy }(1=\text { less than } 5,2= \\
5<15,3=15<25,4=25<35,5= \\
\text { more than or equal to } 35 \text { years })\end{array}$ \\
\hline $\begin{array}{l}\text { h. Farmer group } \\
\text { member }\end{array}$ & $\begin{array}{l}\text { Become a member of the farmer } \\
\text { group }\end{array}$ & Dummy $(1=$ yes, $2=$ no \\
\hline 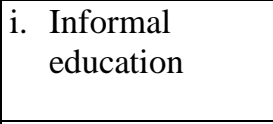 & $\begin{array}{l}\text { Have participated in the } \\
\text { training, extension, seminar, } \\
\text { and/or workshop programs }\end{array}$ & Dummy (1=yes, $2=$ no $)$ \\
\hline $\begin{array}{l}\text { j. } \\
\text { Number of } \\
\text { sheep }\end{array}$ & $\begin{array}{l}\text { Total number of sheep kept by } \\
\text { farmers in Animal Unit }\left(\mathrm{AU}^{\mathrm{a}}\right)\end{array}$ & $\begin{array}{c}\text { Dummy }(1=\text { less than } 1.00,2= \\
1.00-4.00,3=\text { more than } 4.00 \\
\text { AU })\end{array}$ \\
\hline
\end{tabular}

${ }^{\mathrm{a}} \mathrm{AU}$ is an Animal Unit which an adult sheep equal 0.17 $\mathrm{AU}$, young sheep $=0.12 \mathrm{AU}$, lamb $=0.06 \mathrm{AU}$ [18]. 
Table 2. Animal and environment health management practices

\begin{tabular}{|c|c|c|c|c|}
\hline Management aspects & Practices & $\begin{array}{l}\text { Given } \\
\text { score }\end{array}$ & Frequency & Percentage \\
\hline \multicolumn{5}{|l|}{$\begin{array}{l}\text { Animal health } \\
\text { management aspects }\end{array}$} \\
\hline \multirow{2}{*}{ a. Exercise } & No exercise & 1 & 46 & 95.8 \\
\hline & Do exercise & 2 & 2 & 4.2 \\
\hline \multirow{2}{*}{ b. Grooming } & No grooming & 1 & 36 & 75.0 \\
\hline & Do grooming & 2 & 12 & 25.0 \\
\hline \multirow[t]{3}{*}{ c. Wool shearing } & More than 1 years & 1 & 14 & 29.2 \\
\hline & 6-12 month & 2 & 19 & 39.6 \\
\hline & Less than 6 months & 3 & 15 & 31.3 \\
\hline \multirow[t]{2}{*}{$\begin{array}{l}\text { d. Supplement } \\
\text { feeding }\end{array}$} & $\begin{array}{c}\text { Not given supplementary } \\
\text { feed }\end{array}$ & 1 & 40 & 83.3 \\
\hline & Given supplementary feed & 2 & 8 & 16.7 \\
\hline \multirow[t]{2}{*}{ e. Water drinking } & Not given drinking water & 1 & 38 & 79.2 \\
\hline & Given drinking water & 2 & 10 & 20.8 \\
\hline \multicolumn{5}{|l|}{$\begin{array}{l}\text { Environmental health } \\
\text { management aspects }\end{array}$} \\
\hline \multirow[t]{3}{*}{$\begin{array}{l}\text { a. Sheepfold } \\
\text { sanitation }\end{array}$} & More than 4 weeks & 1 & 10 & 20.8 \\
\hline & 1 to 4 weeks & 2 & 32 & 66.7 \\
\hline & Less than 1 week & 3 & 6 & 12.5 \\
\hline \multirow[t]{3}{*}{ b. Waste processing } & Fresh livestock waste & 1 & 18 & 37.5 \\
\hline & Dried livestock waste & 2 & 18 & 37.5 \\
\hline & Fermented livestock waste & 3 & 12 & 25.0 \\
\hline \multirow[t]{3}{*}{ c. Waste removal } & More than 3 months & 1 & 9 & 18.8 \\
\hline & 1 to 3 months & 2 & 19 & 39.6 \\
\hline & Less than 1 month & 3 & 20 & 41.7 \\
\hline
\end{tabular}

\section{Results and Discussions}

The results of the study that has been carried out by exploring data from 48 sheep farmers in Batur Village which are observed in several analyzes, including farmer characteristics, practices in the animal and environmental health management, and the relationship between the farmers' characteristics and both animal and environmental health management practices.

\subsection{Farmer Characteristics}

The farmers' characteristics factors analyzed in this study included: age, formal education, main works, size household, family labor, livestock purpose, livestock experience, farmer group members, informal education, and the number of livestock. Characteristics were the properties or traits that a person shown in mindset patterns, attitude patterns, and action patterns towards the environment. The properties or traits that are owned, including several factors or elements attached to a person, can be said to be a characteristic [19]. Respondent's characteristics factors in this study are presented in Table 3.

\subsubsection{Age of respondents}


Age is an aspect of the farmer's characteristics that affect the biological and psychological functions of individual farmers [16]. The age of respondents in this study was dominated by age $30<40$ years $(35.4 \%)$. The age of farmers in Batur Village based on the Central Bureau of Statistics [20] is included in the productive age, which is between 15 and 64 years. In general, someone who belongs to the productive age can work and think better. Increasing a person's age will also increase the ability to consider and to reason also think creatively to solving a problem [19].

Table 3. Descriptive statistic of the variables

\begin{tabular}{|c|c|c|c|}
\hline Characteristics variables & Dummy & Average value & Percentage $(\%)$ \\
\hline Age & & $2.69 \pm 1.21$ & \\
\hline a. $<30$ years & 1 & 8 & 16.7 \\
\hline b. $30<40$ years & 2 & 17 & 35.4 \\
\hline c. $40<50$ years & 3 & 8 & 16.7 \\
\hline d. $50<60$ years & 4 & 12 & 25.0 \\
\hline e. $\geq 60$ years & 5 & 3 & 6.3 \\
\hline Formal education & & $2.50 \pm 0.90$ & \\
\hline a. Have no formal education & 1 & 2 & 4.2 \\
\hline b. Elementary school & 2 & 30 & 62.5 \\
\hline c. Junior-high school & 3 & 7 & 14.6 \\
\hline d. Senior-high school & 4 & 8 & 16.7 \\
\hline e. College graduate & 5 & 1 & 2.1 \\
\hline Main works & & $2.65 \pm 1.38$ & \\
\hline a. $\quad$ Sheep farmers & 1 & 5 & 10.4 \\
\hline b. Crop Farmers & 2 & 27 & 56.3 \\
\hline c. Farmworkers & 3 & 6 & 12.5 \\
\hline d. $\quad$ Traders & 4 & 4 & 8.3 \\
\hline e. $\quad$ Village officials & 5 & 2 & 4.2 \\
\hline f. $\quad$ Others & 6 & 4 & 8.3 \\
\hline Size household & & $2.19 \pm 0.39$ & \\
\hline a. $1-2$ people & 1 & 0 & 0 \\
\hline b. 3-4 people & 2 & 39 & 81.3 \\
\hline c. 5-6 people & 3 & 9 & 18.8 \\
\hline Family labor & & $1.31 \pm 0.47$ & \\
\hline a. 1-2 people & 1 & 33 & 68.8 \\
\hline b. 3-4 people & 2 & 15 & 31.3 \\
\hline c. 5-6 people & 3 & 0 & 0 \\
\hline Livestock purpose & & $1.94 \pm 0.38$ & \\
\hline a. Primary purpose & 1 & 5 & 10.4 \\
\hline b. Secondary purpose & 2 & 41 & 85.4 \\
\hline c. Hobby & 3 & 2 & 4.2 \\
\hline Livestock experience & & $2.27 \pm 1.09$ & \\
\hline a. $<5$ years & 1 & 14 & 29.2 \\
\hline b. $5<15$ years & 2 & 15 & 31.3 \\
\hline c. $15<25$ years & 3 & 12 & 25.0 \\
\hline d. $25<35$ years & 4 & 6 & 12.5 \\
\hline e. $\geq 35$ years & 5 & 1 & 2.1 \\
\hline Farmers group members & & $1.38 \pm 0.49$ & \\
\hline a. Yes & 1 & 30 & 62.5 \\
\hline b. No & 2 & 18 & 37.5 \\
\hline
\end{tabular}




\begin{tabular}{|c|c|c|c|}
\hline Informal education & & $1.63 \pm 0.49$ & \\
\hline a. Yes & 1 & 18 & 37.5 \\
\hline b. No & 2 & 30 & 62.5 \\
\hline Number of sheep & & $1.75 \pm 0.73$ & \\
\hline a. $<1.00 \mathrm{AU}$ & 1 & 20 & 41.7 \\
\hline b. $1.00-4.00 \mathrm{AU}$ & 2 & 20 & 41.7 \\
\hline c. $>4.00 \mathrm{AU}$ & 3 & 8 & 16.7 \\
\hline
\end{tabular}

The distribution of farmers who are classified as productive age is an advantage in implementing livestock health and environmental management practices in Batur Village. This is because in implementing the management, strong physical power is needed from the farmers, starting from sheepfold cleaning, waste cleaning, waste processing, waste removal, and animal health maintenance activities. At their productive age, farmers are expected to be able to carry out maximum livestock activities because farmers tend to be more active, move faster, and more receptive to directions [19]. Younger farmers have better working abilities, relatively stronger stamina and endurance. Young farmers are generally more open to new things, willing to try to provide new experiences and knowledge to the other farmers, so they can stimulate farmer creativity to explore their resources [21].

\subsubsection{The education level of respondents}

Formal education is the level of education from the lowest to the highest which is usually organized and programmed by the institution. The farmer's level of formal education will affect the level of knowledge and insight. The higher the level of formal education of farmers is expected to be more rational in their mindset and reasoning power [17,22,23]. According to the result, the level of formal education for farmers in Batur village is dominated by the elementary school (62.5\%). The level of formal education of farmers with education above primary education (9 years) only reached $18.8 \%$ ( 9 respondents), this is less supportive of the implementation of animal and environmental health management practices in Batur village to more quickly developed. This is because a higher education level of farmers tends to influence and improve ways of thinking and the level of acceptance of new technologies and innovations, where someone who has the knowledge and skills can better utilize the potential that exists within and outside himself [19].

\subsubsection{Main works and livestock purpose}

The main works of respondents in Batur village are dominated by crop farmers $(56.3 \%)$. Only $10.4 \%$ have the main job as sheep farmers as the primary purpose, while $85.4 \%$ of respondents keep sheep only as a secondary purpose and $4.2 \%$ only as a hobby. Crop farmers usually integrate their agricultural activities with sheep farming by providing the feed from the remaining agricultural products such as carrots, carrot leaves, or cabbage leaves and providing compost products for their crops. Apart from crop farmers, some farmworkers also pass the agricultural waste to their livestock. Sheep farmers for primary purposes usually have a relatively larger number of sheep and have more intensive attention to their livestock with the aim of profit. Most smallholder farmers in rural areas kept livestock as a saving and insurance [24]. 


\subsubsection{Size household and family labor}

The size of household and family labor is the number of family members the respondents have. Family labor is the number of family members who participate in sheep farming activities. Family members can have a positive impact on farming practices because their family members can be used as labor [25,26]. Respondents in Batur Village are dominated by the number of family members as many as 3-4 people (81.3\%). Meanwhile, the largest number of families involved in livestock activities was 1-2 people $(68.8 \%)$. The family members who participate in the farming activities are usually their husbands, wife, and children. The more family members there are the more family members directly involved to maintain the farm that will be easier to obtain the farming business. But on the other hand, the more family members the farmer has, the more life burdens the farmer family must bear [27].

\subsubsection{Livestock experience}

Livestock experience is the length of time that farmers have passed in running a livestock business. The longer the experience the farmer has, the wiser he will be in making decisions. More experienced farmers will be quicker to analyze innovations and surely implement them to increase the benefits [12,25]. Based on Table 3, it is known that sheep farmers in Batur Village have more than five years of farming experience $(70.8 \%)$. The longer the farming experience, the more knowledge the farmers will know to encourage the development of their livestock business. Nurdiyansah et al. [25] stated that livestock experience was a very important role in determining the success of farmers in improving the development of the farming business and the income of farmers. Farming experience is a good teacher, with sufficient experience, the farmer will be more careful in acting and could learn from the experience to be better.

\subsubsection{Farmer group members}

Most of the respondents in Batur Village belong to farmer groups (62.5\%). Each farmer group in Batur Village has a sheepfold for the member of the group on certain land. This is useful for various farmer group activities such as a member gathering place, a place for collecting and processing the waste, to maintain the rams, and useful for the mating process. However, not all members of the farmer groups keep their sheep in the group's sheepfold. Some of them maintain their sheep in a pen near their own houses. The presence of these farmer groups enables them to transfer knowledge and sharing about the problem easier. Besides, by joining farmer groups, the implementation of maintenance management such as the process of mating and the implementation of counseling and assistance by the institution is easier. Abdullah [16] stated that farmer groups have a role and function in developing the capacity of farmers. Farmers who are belonging to farmer groups are easier to learning and interacting with fellow farmers, increasing members skills in developing independent and sustainable livestock businesses, sheltering and channeling members' aspirations, solving problems that arise among members, and making it easier to implement training and counseling.

\subsubsection{Informal education}

Informal education in this study is the participation of farmers in participating in training activities, counseling, seminars, and/or workshop programs. Farmers' informal education is related to how much knowledge farmers gain both technical and managerial [28]. The 
farmers' participation in informal education in Batur Village related to animal health and environmental management practices is still low (62.5\%). This is because most of them have other main jobs which make them have no time to attend counseling or training. Participants who take part in the training are usually representatives of their group. This creates an obstacle in the delivery of information related to good livestock management from the expert. Widarni et al. [29] stated that farmers who attend training more frequently will get more information and skills needed to apply good management practices. Higher education and training can increase farmer awareness and readiness to adopt good farm management practices.

\subsubsection{Number of sheep}

The number of sheep ownership reflects the business scale of a livestock business. The business scale is the size of the business that determines the amount of yield obtained by the farmer in terms of the physical aspect of the business activity. The business scale will affect the level of income, where the higher the business scale of ownership, the greater the income level of farmers [19]. The number of sheep ownership in this study was classified as low with average ownership of $2.10 \pm 2.47 \mathrm{AU}$ with the median of $1.09 \mathrm{AU}$ or equivalent to 6.41 adult rams. The relatively low business scale affecting in less optimal motivation to obtain the farming business. Nurdayati et al. [30] stated that the number of livestock correlated with the farmer motivation. It because the wider farm business scale affects the farmer to accept the innovation more quickly.

\subsection{Animal and Environmental Health Management Practices}

\subsubsection{Animal health management practice}

The aspects and scoring of animal health management practices in this study are presented in Table 2. The aspects observed in this study include exercise, grooming, wool shearing, supplement feeding, and water drinking. Based on the scoring of the activities carried out, then the level categorization is presented in Figure 1. Based on the category level of animal health management practices carried out by farmers, it shows that farmers in Batur Village are dominated by low levels $(83.3 \%)$ in animal health management practices.
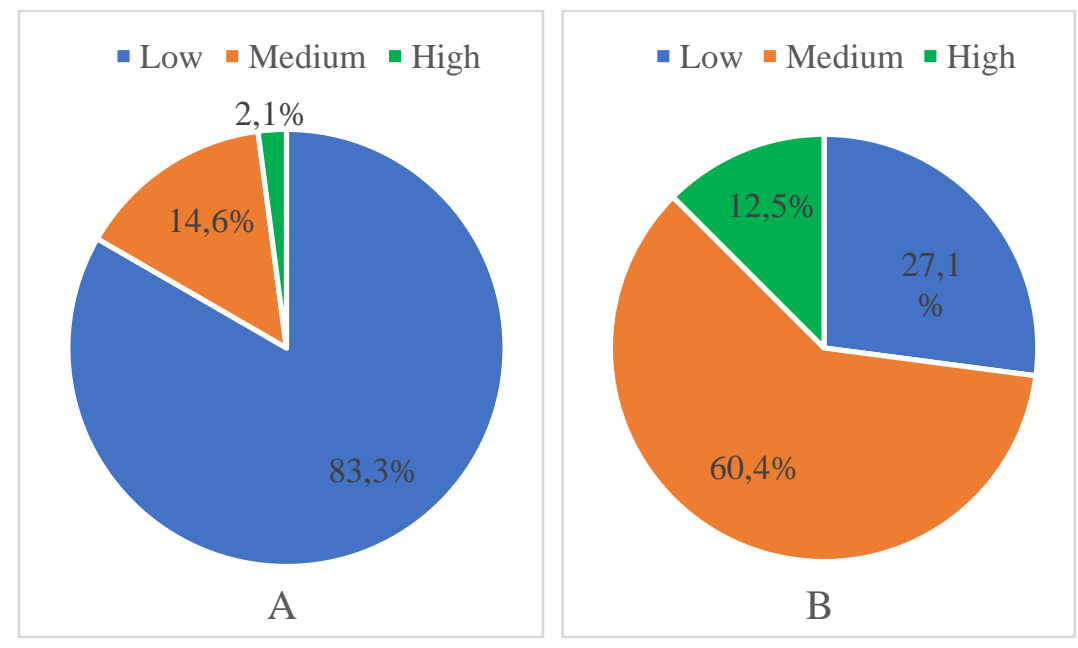

Fig. 1. Animal (A) and environmental (B) health management practices level 
Exercise is one of the indicators of animal welfare in terms of being free from discomfort and free to express normal behavior [31]. The exercise indicator in this study is whether the sheep are kept in the pens continuously or they have time to graze. If a sheep is kept in pens continuously, it is said that it is not exercised, but if the sheep have time for grazing it is called exercise. Most of the farmers in Batur Village (95.8\%) did not give time for exercise. The sheep are fully reared in the pens and only released during certain activities, such as livestock contests, shearing, and mating, but they have no grazing times

Grooming in this study is the process of bathing sheep. Bathing in livestock is very necessary to maintain the cleanliness and health of livestock so that they are not susceptible to disease [32]. Most of the farmers did not groom their sheep (75.0\%). Some others grooming their sheep at least once a year when joining the Batur sheep contest. The cold climatic conditions and high humidity in Batur Village make it impossible for farmers to grooming their sheep because the drying process is relatively difficult and worried about animal health, such as flu and cold. For farmers who take part in the contest, because one of the assessments of the contest is the purity of the breed as seen from the shape of the wool on the body [4], they will care for the sheep that take part in the contest by washing and arranging the wool on the sheep. However, some farmers just shaving their sheep's wools to prepare for the contest without grooming due to worried about the animal health

In this study, all of our respondents are the Batur sheep farmers who can give the real condition about the farming practices in the field. The characteristic of the Batur sheep is all of the body is a coat with wool-like Merino sheep [5]. This is suitable for the environment in Batur Village which has a low temperature. On the other hand, to make the sheep still comfortable, shearing the wool is needed to maintain cleanliness and prevent disease also give optimal productivity. All sheep farmers in this study shaved their sheep. Shearing is one of the practices that is applied periodically to fiber-producing animals. Shearing in sheep can affect the ability of thermoregulation to support adaptation and make the animal feel comfortable in the environment [33]. The shaving period was mostly done every 6 to 12 months (39.6\%). Fleece shearing time is usually done in suitable climatic conditions. Sheep are shaved at least once a year [34]. Farmers usually shearing their sheep at the time of breeding. This is in line with the statement of Dyrmundsson [34] that shearing wool can accelerate the time of the first estrus in adult sheep

Most of the farmers in Batur Village do not provide supplement feed (83.3\%) for their sheep. The supplement feed in this study is concentrate feed and feed additive. Supplementary feed provided by some farmers is in the form of wheat bran, wheat pollard, and commercial concentrate feed. This supplementary feeding is usually carried out by farmers who have a large number of sheep and run their livestock business as their main job. Most of the farmers in this study have a main job as crop farmers and farm workers. They used to provide leftover feed from agriculture to their sheep. Some of the agricultural waste provided is in the form of carrots, carrot leaves, and cabbage leaves. This can provide benefits for farmers to use their agricultural waste as a source of feed for their livestock [35]. Besides, the abundant forage and agricultural waste in this area can be fulfilled the animal feed needs.

Water is needed for various biological functions and body metabolism. Water requirements in livestock vary, depending on various factors such as the type and size of livestock, the physiological status of the livestock, the level of animal activity, the type and quality of feed, water quality, taste and salinity of water, distance, and size of drinking water, as well as water temperature and air temperature [32]. Farmers rarely provide drinking water for sheep in Batur Village. As many as $79.2 \%$ of respondent farmers do not provide drinking water specifically for their sheep. They do this because the water needs of the animal are fulfilled from the forage they provide, which is they give fresh forage with a high enough water content. For some other reasons, they afraid to provide drinking water due to some 
experiences that made their sheep bloated. This is rational because of the environmental conditions in Batur Village in the highlands. Some farmers who provide drinking water to their sheep are usually farmers who provide supplementary feed to their sheep. They mixed the concentrate feed with drinking water and given to the sheep. However, no one gave their sheep drinking water ad libitum. Drinking water is given only at certain times and when it is enough, the farmer will take it back. Usually given after feeding concentrate or during the day and taken back in the afternoon.

\subsubsection{Environmental health management practice}

Environmental health management practices observed in this study are sheepfold sanitation, waste processing, and waste removal. Scoring for each aspect of environmental health management practice is presented in Table 2. The results of the cumulative score are further categorized into three levels as presented in Figure 1. Based on this scoring, it appears that the medium level (58.3\%) is dominant in Batur Village regarding environmental health management practice, followed by low levels (29.2\%) and high levels (12.5\%). This shows that farmers in Batur Village are quite good at handling sheepfold cleanliness and waste management.

A clean house is a crucial factor for animal health. The dirty house could increase the risk of disease exposure. Sick animal, they will be lost appetite and decreasing the body condition score, this condition will affect the physiological function and metabolism in the body [32]. The sheepfold cleaning period of farmers varies enough, from daily cleaning to once every 4 weeks. The highest percentage used to clean the cage is once every one to four weeks $(66.7 \%)$. Cleaning of the sheepfold is done by cleaning the area under the pens and collecting the waste around the sheepfold or in the feces collection area. If the period of sheepfold cleaning short, it will be better for sheepfold cleanliness. When the cleaning process, it is also possible to check the condition of the pens if it is damaged and they could be repaired immediately.

Waste produced by livestock activities, such as feces and feed residue, is then removed and collected in the waste processing facility. Based on the processing method, this study is divided into three categories [14], namely (1) fresh livestock waste, which is sheep feces collected and disposed of without special treatment and no mixing or drying with other materials, (2) dried livestock waste, which is feces and the remaining feed is collected and stored first until it becomes fertilizer but not mixed with other ingredients and sell it as fertilizer, (3) fermented livestock waste, which is sheep feces and feeds waste is collected and mixed with the ingredients such as molasses and starters (EM4®) over a period of time and then used as fertilizer. Dried livestock waste is considered simpler and easier for farmers to do. Some farmers who keep their sheep in farmer group's sheepfold usually have their own place to collect the droppings which are usually behind the sheepfold. However, there is also a farmer group's sheepfold that provides a special place to collect the waste. Farmers who have an individual sheepfold near their house, usually carry out the shelter only under the pens, and then transferred and use it as fertilizer when it is ready.

The period for removing waste from the shelter also varies from less than 1 month to more than three months. Most farmers collect sheep feces for less than one month $(41.7 \%)$ and then throw it away. Waste collected and treated with fresh waste is usually faster to be transferred, on the other hand, it will take a longer time to dried and fermented waste to be used as fertilizer or sale. Some farmers do not carry out the collection and directly throw the livestock waste into the fields at the edge of the sheepfold or even flow it into the river. However, if the disposal is not carried out properly, it will pollute the other environment, so there is a need for efforts in handling and processing the livestock waste so it can be used optimally. 
Sheepfold sanitation is carried out to maintain animal health through environmental hygiene. The frequent frequency of sheepfold sanitation will be better. Sanitation of the sheepfold should be carried out thoroughly, surrounding the environment and the equipment related to livestock. A dirty and neglected environment is a good condition for various disease-spreading insects [32].

\subsection{The Relationship between Farmer Characteristics with the Animal and Environmental Health Management Practices}

The relationship between farmers' characteristics with animal and environmental health management practices in Batur Village, Banjarnegara Regency could be observed in Table 4. It can be seen that the variables of informal educations, livestock experience, and the number of sheep kept by farmers have a significant relationship with the animal health management practices. Similarly, the variables of formal education, livestock purpose, livestock experience, and the number of sheep kept by farmers had a significant relationship with environmental health management practices. Most of the correlation coefficient values for these variables are in the range of $0.20 \leq \mathrm{r}<0.40$, where according to Guilford's rule, the relationship of these variables is weak except for the variables livestock experience (animal health management practice) and the number of sheep (environmental health management practice) which has a quite meaningful relationship with a range of $0.40 \leq \mathrm{r}<0.70$ and the sign $(+)$ or $(-)$ determines the direction of the relationship [36,37].

Table 4. Spearman's rank correlation between farmers' characteristics toward animal and environmental health management practices

\begin{tabular}{|c|c|c|c|c|}
\hline \multirow{2}{*}{$\begin{array}{c}\text { Farmers' } \\
\text { characteristics }\end{array}$} & \multicolumn{2}{|c|}{$\begin{array}{l}\text { Animal health management } \\
\text { practice }\end{array}$} & \multicolumn{2}{|c|}{$\begin{array}{l}\text { Environmental health } \\
\text { management practice }\end{array}$} \\
\hline & $\begin{array}{c}\text { Correlation } \\
\text { coefficient (r) }\end{array}$ & p-value ${ }^{a}$ & $\begin{array}{l}\text { Correlation } \\
\text { coefficient }(r)\end{array}$ & p-value \\
\hline Age & 0.240 & 0.100 & -0.075 & 0.614 \\
\hline Formal education & 0.223 & 0.127 & 0.346 & $0.016^{*}$ \\
\hline Main works & -0.039 & 0.793 & -0.241 & 0.099 \\
\hline Size household & 0.229 & 0.117 & 0.031 & 0.834 \\
\hline Family labor & 0.053 & 0.722 & 0.104 & 0.480 \\
\hline Livestock purpose & -0.069 & 0.641 & -0.307 & $0.034 *$ \\
\hline Livestock experience & 0.428 & $0.002 * *$ & 0.313 & $0.030 *$ \\
\hline $\begin{array}{l}\text { Farmer group } \\
\text { members }\end{array}$ & -0.101 & 0.495 & 0.050 & 0.736 \\
\hline Informal education & -0.351 & $0.015^{*}$ & -0.175 & 0.235 \\
\hline Number of sheep & 0.339 & $0.018^{*}$ & 0.573 & $0.000 * *$ \\
\hline
\end{tabular}

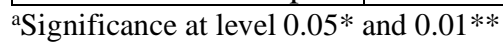

Formal education has a significant and positive correlation with environmental health management practices by farmers, but not with animal health management practices. This is in line with the research of Du et al. [13] that education level had a significant influence on environmental awareness. Farmers' knowledge about animal and environmental health management aspects is specifically not obtained in formal schools. However, the level of formal education of the farmers will show the level of knowledge and insight of the farmers themselves, which influences the farmers in adopting the right technology in their farming activities later. The higher the level of formal education affect the farmer to be more rational in their mindset $[22,23]$. Thus, the formal education level of farmers will affect their ability to respond to innovation. 
Livestock experience has a significant influence and positively correlates with animal health management practices and environmental health management practices. This indicates that the longer the experience of the farmer in this field, the higher possibility to have good management practices. The longer the farming experience, the more practical and technical knowledge that will be obtained. Apart from being obtained from hereditary experiences, farming experiences are also obtained from observations from the surrounding environment [38]. The more experience in farming, the farmers will be more careful in trying and be able to correct the past bad experience [12].

A positive correlation is also shown between the number of sheep ownership and both animal and environmental health management practices. This indicates that the more sheep the farmers have, the higher the possibility for the farmers to carry out animal and environmental management practices. This is because the number of animals will affect decision-making in the management of livestock. According to the opinion of Rahmah and Somanjaya [17], the high scale of livestock business affects an interest in the latest technology, assuming that if they fail there is still some livestock that is expected and vice versa farmers who have small scale businesses feel hesitate to apply the latest technology because of worried to failure.

In this study, livestock purpose has a significant effect on environmental health management practices but not on animal health management practices. A negative correlation is seen in this study, which means that farmers who farming as the main purpose for their livelihoods are more likely to implement environmental health management practices. Farmers who carry out animal husbandry as their main job tend to have more time to take care of sheepfold and carry out environmental health practices. Farmers who farming for side business are more likely to pay less attention to the productivity of their livestock [38]. However, in this study, there was no significant relationship between livestock objectives and animal health management practices. This indicates that the animal health management practices observed in this study can be carried out by farmers with a primary purpose, secondary purpose, or just a hobby.

A negative correlation is also seen between informal education and animal health management practice, but not with the environmental health management practice. In this study, it can be indicated that farmers who have attended informal education such as counseling and training will have a higher probability of implementing animal health management. Most of the farmers still apply low animal health management, so that they often find some cases of mild disease in the animal. This encourages farmers to gather information related to animal health, one of which is through extension activities [16]. Environmental health management practice also has a negative correlation coefficient value, but the effect is not significant. This can be due to the fact that they have had a long experience in farming and implementing the practice even without the following counseling.

The variables age, main works, household size, family labor, and farmer group members do not have a significant effect on both animal and environmental health management practices. Age will affect the ability of farmers to learn, understand, accept and adopt technology and increase their work productivity $[13,16]$. In this study, most of the farmers in Batur Village were classified as of productive age, so that the possible effect on the implementation of animal health and environmental management was not significant because this practice could be implemented by both young and old farmers easily. This is in line with the research of Supriyanto et al. [22] that there is no significant relationship between age and the level of farmer adoption of technology where technology adoption can be applied by anyone regardless of age.

The main occupation of the respondent does not have a significant effect on animal health management practices or the environment. It because most farmers do not raise sheep for main works and only for a secondary purpose. So they are not enthusiastic to find out animal 
and environmental health management practices. Ideally, the more focused the work is in the field, the higher the response to implementing better management practices in the business. On the other hand, if the management is deemed important to do, it will be done by farmers even with their different main jobs. This can be seen from the purpose of their livestock business, there is a significant correlation with environmental health management but not with animal health management. It means that farmers with different main occupations are already aware of carrying out animal health management and vice versa, they are still less enthusiastic about implementing environmental health management practices.

The more the number of members in the farmer family, the more dependents of the farmer family will increase, which will be increasing the budget for living that also reduce income from livestock business [39]. On the other hand, the number of family members can also have a positive impact on the livestock business because the family members can help as labor [25]. Some farmers have a problem with motivation because there are no ideas due to focusing on financial problems. Farmers with a small number of family members tend to have great motivation to maintain the livestock business and increase income [39]. However, in this study, there was no significant effect on animal and environmental health management practices. This indicates that the health management practices observed in this study are not influenced by the number of family members or the number of families that carry out these activities. Although, a small number of workers can still be implemented. It in line with the opinion of Supriyanto et al. [22] that the number of family dependents does not have an impact on the adoption rate of the farmers but rather leads to income and the family economy.

Farmer groups have a role and function in developing the capacity of farmers. It is hoped that farmers who are joining the groups will easier interact with members to solve problems or sharing about innovations to developing their livestock business [16]. However, the farmer group members in this study did not affect animal and environmental health management practices. This is probably because many members did not put their livestock animals in the farmer group's sheepfold, so the new information and innovations do not deliver for all members. Not all of the group members can attend counseling and training because usually just group leaders or administrators of the group. It would be difficult to deliver comprehensive information for all group members.

Farmer demographics, which include both farmer and farm characteristics, affect several aspects of human, animal, and environmental health. In the concept of One Health, the interaction between human-animal-environment and socio-ecology is very related and important. The One Health approach aims to achieve optimal health for humans, animals, and the environment $[7,10]$. Animal and environmental health issues in livestock activities need to be discussed and handled appropriately so that healthy humans, animals, and ecosystems can be achieved. Formal and informal education, as well as farmers' experiences in this study, play a significant role in animal health and environmental health management practices. Therefore, there is a need for further training and extension to form awareness of farmers in carrying out good livestock management practices so that not only their livestock production increases but also supports the application of environmental health. To contribute to building a One Health and transdisciplinary approach, it is necessary to have a program for training and research that is applied with multidisciplinary and intersectoral collaboration [8]. This approach requires an integrative and systemic research method that will facilitate the deconstruction of academics, institutions, disciplinaries, stakeholders, and government [40]. Given the required participation from various sectors, it is necessary to design a framework that can represent various types of targeted intervention, social, and geographic contexts [9]. In this study, only a small part of the animal and environmental health aspects were observed. There are still many areas that need to be studied and observed, especially the achievements and their relation to the One Health concept. 


\section{Conclusion}

The results may conclude that the low and medium levels of animal and environmental health management practices were dominant in Batur Village. This is related to farmers' characteristics, such as formal education, livestock purpose, livestock farming experience, informal education, and the number of sheep that were kept by farmers. Further extension and assistance were needed to improve the management practices so that healthy livestock activities can be realized, both in the animal and environmental aspects.

The authors are thankful to the Director-General of Higher Education, Ministry of Education and Culture of the Republic of Indonesia, for funding this study with the Pendidikan Magister menuju Doktor untuk Sarjana Unggul Program (Grant No. 27/E1/KPT/2020 with contract no. 3175/UN1.DITLIT/DIT-LIT/PT/2020). The authors also thank the Faculty of Veterinary Medicine Universitas Gadjah Mada for the support and thank all respondents.

\section{References}

1. Central Bureau of Statistics, Statistik Daerah Kecamatan Batur 2016 (Central Bureau of Statistics of Banjarnegara Regency, Banjarnegara, 2016)

2. Ministry of Agriculture, Keputusan Menteri Pertanian Nomor 2916/Kpts/OT.140/6/2011 Tentang Penetapan Rumpun Domba Batur (Ministry of Agriculture of the Republic of Indonesia, Jakarta, Indonesia, 2011)

3. A. Sodiq, P. Yuwono, and S. A. Santosa, Anim. Prod. 13, 166 (2011)

4. A. Ibrahim, I. G. S. Budisatria, R. Widayanti, B. A. Atmoko, and W. T. Artama, IOP Conf. Ser. Earth Environ. Sci. (to be published)

5. A. Ibrahim, I. G. S. Budisatria, R. Widayanti, B. A. Atmoko, R. Yuniawan, and W. T. Artama, Adv. Anim. Vet. Sci. 8, 1028 (2020)

6. J. E. Duval, N. Bareille, C. Fourichon, A. Madouasse, and M. Vaarst, Prev. Vet. Med. 146, 16 (2017)

7. K. Shrestha, K. P. Acharya, and S. Shrestha, Int. J. One Health 4, 8 (2018)

8. D. I. Sidikou, Y. Caron, C. Delguste, A. I. Ibrahim, M. L. Ibrahim, H. Adakal, J. L. Hornick, and N. Antoine-Moussiaux, Int. J. One Health 6, 69 (2020)

9. S. E. Baum, C. Machalaba, P. Daszak, R. H. Salerno, and W. B. Karesh, One Heal. 3, 5 (2017)

10. E. K. Rousham, L. Unicomb, and M. A. Islam, Proc. R. Soc. B Biol. Sci. 285, 20180332 (2018)

11. A. Ibrahim, I. G. S. Budisatria, R. Widayanti, and W. T. Artama, Vet. World 13, 2625 (2020)

12. N. Hidayah, C. A. Artdita, and F. B. Lestari, J. Bisnis Dan Manaj. 19, 1 (2019)

13. Y. Du, X. Wang, D. Brombal, A. Moringgi, A. Sharpley, and S. Pang, Sustainability 10, 1 (2018)

14. N. A. A. Widarni, A. Astuti, S. Andarwati, T. A. Kusumastuti, and A. R. S. Putra, IOP Conf. Ser. Earth Environ. Sci. 518, 012046 (2020)

15. O. Fonseca, K. R. Santoro, P. Alfonso, J. Ayala, M. A. Abeledo, O. Fernández, Y. Centelles, D. de las N. Montano, and M. I. Percedo, Int. J. One Health 3, 36 (2017)

16. A. Abdullah, Ziraa'ah 41, 127 (2016)

17. U. I. L. Rahmah and R. Somanjaya, J. Ilmu Pertan. Dan Peternak. 7, 102 (2019)

18. Natural Resources Conservation Service, in Natl. Range Pasture Handb. (United States Department of Agriculture, Washington, 2003), pp. 1-19

19. S. Andarwati, T. Haryadi, B. Guntoro, E. Sulastri, R. A. R. S. Putra, and Gunawan, Bull. Anim. Sci. 42, 256 (2018)

20. Central Bureau of Statistics, Cent. Bur. Stat. (2017) 
21. A. Sucipto, M. Sugiarto, K. Muatip, O. E. Djamiko, and H. Aunurrohman, in Pros. Semin. Teknol. Dan Agribisnis Peternak. VI (2018), pp. 297-301

22. Supriyanto, A. C. Budy, and Z. Arifin, J. Pengemb. Penyul. Peternak. 16, 4 (2019)

23. I. G. S. Budisatria, E. Baliarti, T. S. M. Widi, and A. Ibrahim, in Simp. Nas. Penelit. Dan Pengemb. Peternak. Trop. Tahun 2016 (Faculty of Animal Science, Universitas Gadjah Mada, Yogyakarta, 2016), pp. 236-243

24. I. G. S. Budisatria, Panjono, D. Maharani, and A. Ibrahim, Kambing Peranakan Etawah: Kepala Hitam Atau Cokelat? (Gadjah Mada University Press, Yogyakarta, 2018)

25. I. Nurdiyansah, D. Suherman, and D. Putranto, Bul. Peternak. Trop. 1, 64 (2020)

26. S. T. Rohani, A. R. Siregar, T. G. Rasyid, M. Aminawar, and M. Darwis, IOP Conf. Ser. Earth Environ. Sci. 486, 012047 (2020)

27. Y. Tadesse, Open J. Anim. Sci. 9, 217 (2019)

28. Y. Muharastri, R. Pambudy, and W. B. Priatna, JSEP 8, 25 (2015)

29. N. A. A. Widarni, T. A. Kusumastuti, and A. R. S. Putra, J. Indones. Trop. Anim. Agric. 45, 356 (2020)

30. Nurdayati, N. I. Fidin, and Supriyanto, J. Pengemb. Penyul. Pertan. 17, 121 (2020)

31. C. J. Phythian, E. Michalopoulou, P. H. Jones, A. C. Winter, M. J. Clarkson, L. A. Stubbings, P. J. Cripps, and J. S. Duncan, Animal 5, 943 (2011)

32. S. Suharyati and M. Hartono, J. Penelit. Pertan. Terap. 16, 61 (2016)

33. E. Pehlivan, M. Kaliber, Y. Konca, and G. Dellal, Asian-Australasian J. Anim. Sci. 33, 848 (2020)

34. O. R. Dyrmundsson, Buvisindi Icel. Agr. Sci 5, 39 (1991)

35. A. R. S. Putra, N. A. A. Widarni, W. Bawono, R. Agustine, and T. A. Kusumastuti, IOP Conf. Ser. Earth Environ. Sci. 387, 012115 (2019)

36. U. I. L. Rahmah, J. Ilmu Pertan. Dan Peternak. 2, 1 (2014)

37. L. Inozemtseva and R. Holmes, Proc. - Int. Conf. Softw. Eng. 435 (2014)

38. R. Wea, PARTNER 15, 178 (2008)

39. Ibrahim, Supamri, and Zainal, J. Soc. Agric. Econ. 13, 307 (2020)

40. B. Min, L. K. Allen-Scott, and B. Buntain, Prev. Vet. Med. 112, 222 (2013) 